https://helda.helsinki.fi

\title{
The realization of pitch reset in Finnish print interpreting data
}

\section{Wiklund, Mari}

2014

Wiklund, M 2014 , ' The realization of pitch reset in Finnish print interpreting data ', Text \& pÿTalk , vol. 34 , no. 4 , pp. 491520 . https://doi.org/10.1515/text-2014-0013

http://hdl.handle.net/10138/298461

https://doi.org/10.1515/text-2014-0013

unspecified

publishedVersion

Downloaded from Helda, University of Helsinki institutional repository.

This is an electronic reprint of the original article.

This reprint may differ from the original in pagination and typographic detail.

Please cite the original version. 


\title{
Mari Wiklund
}

\section{The realization of pitch reset in Finnish print interpreting data}

\begin{abstract}
Speakers use intonation in order to group spoken sentences together into larger units. One such grouping is often referred to as "paragraph intonation." One of its principal characteristics is that the beginning of a new speech paragraph is marked with a high pitch level at the beginning of the first spoken sentence. This phenomenon is called "pitch reset." The present article discusses the role of the pitch reset in Finnish data coming from two situations where conference-like monologous presentations are being interpreted by professional print interpreters. "Print interpreting" is a mode of communication where the speech is being simultaneously transferred into written form so that deaf and hard-of-hearing people can have access to it.

The study shows, on the one hand, that the pitch reset phenomenon can be found also in Finnish data. On the other hand, the results show that the pitch reset constitutes a prosodic sign that almost always leads to a paragraph division in the written target text. This implies that the print interpreters treat speech paragraphs as topical units, and that the pitch reset plays an important role in the structuring of discourse. The study is mainly based on Wichmann's (2000) approach, which constitutes an interface between discourse analysis and intonation studies.
\end{abstract}

Keywords: pitch reset, intonation, Finnish prosody, phonetics, print interpreting, discourse analysis

DOI 10.1515/text-2014-0013

\section{Introduction}

It is well-known that speakers use intonation in order to group spoken sentences together into larger units that could be compared with written text paragraphs. This grouping is often referred to as "paragraph intonation" (Wichmann 2000: 24). One of the principal ideas is that the beginning of a new speech paragraph is

Mari Wiklund: Department of Modern Languages, PO Box 24, 00014 University of Helsinki, Finland.E-mail: mari.wiklund@helsinki.fi 
marked with a high pitch level at the beginning of the first spoken sentence (Brazil et al. 1980; Couper-Kuhlen 1986, 2004; Wichmann 2000). ${ }^{1}$ The subsequent spoken sentences of the same paragraph typically start on a lower pitch level than the first one (Sluijter and Terken 1993; Wichmann 2000). Sometimes this "pitch reset" phenomenon is used to initiate a new topic; in these cases it can be called topic reset (Wichmann 2000: 25). Indeed, the phenomenon seems to be related to the indication of topical transitions, such as a change of topic or subtopic (Barth-Weingarten 2009; Chafe 1994). Sometimes a pitch reset can also indicate the beginning of a new action (Couper-Kuhlen 2004).

Nafá Waasaf (2007) has shown that in simultaneous interpreting (SI) both speakers and interpreters treat the high pitch as a mark of an initial topical boundary. This article will discuss the role of the pitch reset (PR) phenomenon in Finnish data coming from print interpreting situations. "Print interpreting" (PI) is a mode of communication where the speech and other relevant audible information is being simultaneously transferred into written form so that deaf and especially hard-of-hearing people can have access to it (Tiittula 2009). The printed output is supposed to correspond as closely as possible to the spoken input. The print interpreter is, however, obliged to reduce a large number of words. According to Tiittula (2009), about $30-45 \%$ of words are reduced in the PI process. In the present data corpus, approximately $34 \%$ of words are being reduced (Wiklund 2013). The print interpreters use a large font size, which may also play a role in the structuring of the text.

The study aims, on the one hand, at showing that the PR phenomenon can be found also in Finnish data. Indeed, even if phenomena related to paragraph intonation are well-documented in many languages, so far they have not been studied much in Finnish. On the other hand, the article discusses the relationship between the beginnings of speech paragraphs (i.e., occurrences of the PR) and the beginnings of written paragraphs: where intonation contributes to the structuring of speech, written paragraph divisions play an important role in exposing the information structure of a written text (Ji 2008; Stark 1988). The question is: do the changes of speech paragraphs and written text paragraphs match in the PI data where the written target text is supposed to represent the spoken source text as closely as possible? On the basis of the results of Nafá Waasaf (2007), one could expect them to match at least in a certain measure, because if SI interpreters comply with the pitch reset, it seems plausible that print interpreters do the same. If the occurrences of the PR typically coincide with the beginnings of written

1 The notion of the "paratone" has also been used to signify a paragraph-like unit of speech (Brown et al. 1980; Yule 1980). 
paragraphs, is it statistically justified to say that in these data an initial boundary of a written text paragraph constitutes the "written equivalent" of the PR phenomenon of speech? Or are there other factors that also play a role in the indication of a paragraph boundary? Brown et al. (1980: 26) have observed that speech paragraphs - or "paratones" - are usually much shorter than written paragraphs. But is this also the case in the PI data?

According to Aho and Yli-Luukko (2005), there are two categories of intonation units in Finnish and Finno-Swedish dialects: minor and major. "Major intonation units" have clear boundaries. They usually end with a falling pitch and a pause. Sometimes major intonation units end with creaky voice. The last syllables may be completely voiceless or absent. Major intonation units typically consist of things that are closely related (Aho and Yli-Luukko 2005). The authors remark that the global pitch form of a major intonation unit is usually declining, and that its beginning most often entails a remarkable rise in the pitch curve (2005: 210, 212). This unit corresponds structurally to a speech paragraph in the model of Wichmann (2000). However, in the model of Aho and Yli-Luukko (2005), the raised pitch level occurring in the beginning of the unit is only one of its typical features, whereas in Wichmann's (2000) approach, the PR - which is at the center of this article - constitutes a fundamental criterion for the definition of an initial paragraph boundary.

Contrary to major intonation units, "minor intonation units" do not always have clear boundaries (Aho and Yli-Luukko 2005: 210). Their duration is however limited: normally less than two seconds. This might be related to rhythmic factors as well as to the working memory's limited capacity (2005: 210). Sometimes the clearest cue to the boundaries of a minor intonation unit can be related to changes of the level of loudness from high (in the beginning) to low (at the end) (2005: 213-214). In this study, the units that Aho and Yli-Luukko (2005) call "minor intonation units" correspond more or less to "spoken sentences" (Wichmann 2000). A "spoken sentence" is defined here as a unit of speech that corresponds as closely as possible to a grammatical unit called "sentence" in written language. It constitutes an intonation unit that has its own function or its own "idea" (Chafe 1980, 1994). ${ }^{3}$ In conversation, one spoken sentence represents one action. Helasvuo's studies $(2001,2003)$ based on Finnish conversation data have shown that most often the boundaries of intonation units match with those of grammatical units. ${ }^{4}$ A spoken sentence can consist grammatically of a word, a

2 Aho and Yli-Luukko's (2005) data consist of stories told by language guides.

3 In Finnish, this unit could be called lausuma ('utterance') (ISK 2004: §1003).

4 Croft (1995) and Crystal (1969) have obtained similar results in English data. 
phrase, or a clause (ISK 2004: §1003). It does not necessarily include a verb. In my data, a spoken sentence often corresponds grammatically to a clause. However, as a written sentence, it can also sometimes include several clauses, if they constitute only one intonation unit (Du Bois and Schuetze-Coburn 1993). The end of an intonation unit - and consequently also the end of a spoken sentence - is marked with prosodic cues, such as pauses, pitch movements, and changes of intensity, speech rate, and/or duration (Aho and Yli-Luukko 2005; Barth-Weingarten 2011; Cruttenden 1986; Hirvonen 1970; Pierrehumbert 1980; Sadeniemi 1949).

Hirvonen (1970: 39-40) has discovered that a communicative function is expressed with a raised pitch level in the beginning of the breath-group both in interrogative and in imperative utterances of Finnish. ${ }^{5} \mathrm{He}$ also remarks that intonation is used for indicating the limits of breath-groups: a falling pitch is a sign of the end of a larger whole, whereas a non-falling pitch indicates continuity. This parallels findings for French (Morel and Danon-Boileau 1998; Morel 2010). In this approach, an intonation paragraph ends in a pitch fall associated with a decrease in intensity on the last syllable of a syntactic group. A rising pitch, in turn, indicates continuity of the intonation paragraph. In a previous study (Lehtinen 2010), I have applied Morel and Danon-Boileau's (1998) model to Finnish data in order to describe the structure of an "intonation paragraph" of Finnish, and in order to clarify the discourse-structuring functions of sentence-final pitch rises that had been studied earlier from another point of view by Routarinne (2003) and by Ogden and Routarinne (2005). However, in this study, the initial pitch level of a spoken sentence (i.e., the possible occurrence of a PR) defines the limits of speech paragraphs instead of the final features. ${ }^{6}$

\section{Data and methods}

The data come from two situations where conference-like monologous presentations are being interpreted by professional print interpreters. The contents of the talks have been prepared in advance, but the speakers are presenting them rather

5 Hirvonen's (1970: 17) data consist of dialogues composed by the author. A group of informants read the dialogues in a near-unechoic chamber.

6 Morel and Danon-Boileau's (1998) data consist of a large collection of different situations varying from text readings to spontaneous everyday talk-in-interaction. Their approach also takes into account a large number of morpho-syntactic features. For more information on this aspect, cf. Lehtinen (2010). 
spontaneously, without reading a text. Both speakers are native Finnish speakers and adults. One of them is female and the other one is male. The duration of the female speaker's presentation is 9.30 minutes. The male speaker's presentation is one minute shorter. Thus, the total duration of the data is 18.00 minutes. The female informant's talk is the first half of a series of two presentations given by the same speaker. The male informant's talk, in turn, is the beginning of a long lecture.

The study is mainly based on Wichmann's (2000) approach, which constitutes an interface between discourse analysis and intonation studies. In the words of Wichmann (2000: 2), this approach makes use of "both auditory and instrumental analysis, thus taking into account what the listener hears and what the computer can measure." That is, both auditorily transcribed texts and the corresponding sound recordings have been used. The speech analysis program Praat has been used for the acoustic analyses of the data (Boersma and Weenink 2012). The pitch level (F0) has been measured at the moment of the production of the onset (first stressed syllable) of each spoken sentence. ${ }^{7}$

\section{Pitch reset (PR)}

The PR corresponds to the beginning of a new speech paragraph (Wichmann 2000: 24-25). As already mentioned, the phenomenon is often related to the indication of a topical shift, such as a change of topic, a change of perspective, or a change of subtopic (Barth-Weingarten 2009; Chafe 1994). It may also indicate a transition from one action to another (Couper-Kuhlen 2004). The PR - i.e., the beginning of a new speech paragraph - occurs when a spoken sentence starts on

7 In Finnish, the word (primary) stress always falls on the first syllable of the word (Iivonen 1998: 315; Iivonen and Aulanko 2001: 26; ISK 2004: §13; Sadeniemi 1949). Consequently, the onset is always the first syllable of the spoken sentence. According to Iivonen (1998: 316), Finnish stress is relatively weakly expressed. The prominence of the default stress depends on the part of speech of the word: content words (nouns, adjectives, and numerals) typically carry a more prominent stress than verbs and function words (pronouns and conjunctions) (Iivonen and Aulanko 2001: 26-27; Sadeniemi 1949). However, as the spoken sentences of the data rarely start with a content word, the differences related to the part of speech are not very relevant here. The presence or the absence of the pitch reset seems to define whether the first syllable of the spoken sentence is stressed or not, independently of the part of speech of the first word. That is, the discourse-structuring function of prosodic features seems to surpass the sentence stress; a word that may not be important on the level of a sentence can be stressed if it carries a discoursestructuring function that concerns a larger unit. 
a raised pitch level compared with the beginning of the preceding spoken sentence (Brazil et al. 1980; Brown et al. 1980; Couper-Kuhlen 1986, 2004; Lehiste 1975; Wichmann 2000; Yule 1980). In all, the data contain 33 occurrences of the PR. The female speaker's presentation includes 17 occurrences (1.8 per minute), and the male speaker's presentation 16 occurrences (1.9 per minute). Thus, the phenomenon is about as frequent for both speakers.

The first example illustrates the phenomenon in the female informant's speech. Her presentation is about autism spectrum disorders. The speaker is talking about the differences between autism and Asperger Syndrome, both of which belong to autism spectrum disorders. (A list of the conventions of transcription and the abbreviations used in the examples can be found in the appendix.)

1 ja (0.7) ja sanotaan että yleensä Aspergerin oireand and they say that usually Asperger syndrome

2 yhtymällä on ehkä parempi ennuste (0.3) silleen may have a better prognosis kind of

3 tulevaisuuden kannalta että (0.2) itsenäiseen elämään concerning the future (PRT) for an independent life

4 ja näin (0.9) mutta se ömh (.) vaihtelee (0.5) and so but it (PRT) varies

5 että (.) jotkut (1.0) jotkut lapsuusiän autistit saattaa (PRT) some some childhood autists may

6 sitte kuntoutua hyvinkin (0.3) pärjääviksi aikuisiksi then get better so that they get along very well as adults

7 ja toiset Aspergerit sit saattaa tota (0.6) taantua whereas some Aspergers then may er regress

8 jossain vaiheessa tulla takapakkii (0.7) .fff (0.4) at some point backpedal

9 mutta tota (0.8) /autismi/ (0.3) johtuu (2.0) but er autism results

10 ilmeisestikin useista \#tekijöistä et\# semmosta niin apparently from several factors (PRT) there is no sort of (PRT)

11 kun: tiedeyhteisön konsensusta \#ei oo (.) et mistä se er: scientific community's consensus about where it

12 tulee\# (.) > mutta tota< (1.1) /perimä/ > on $y k s<(0.6)$ comes from but er the genotype is one

13 \#tekijä\# sïnä (0.9)

factor in it 
The example includes five spoken sentences:

1 ja ja sanotaan että yleensä Aspergerin oireyhtymällä on ehkä parempi ennuste silleen tulevaisuuden kannalta että itsenäiseen elämään ja näin ('and and they say that usually Asperger syndrome may have a better prognosis kind of concerning the future PRT for an independent life and so', lines 1-4);

2 mutta se ömh vaihtelee ('but it PRT varies', line 4);

3 että jotkut jotkut lapsuusiän autistit saattaa sitte kuntoutua hyvinkin pärjääviksi aikuisiksi ja toiset Aspergerit sit saattaa tota taantua jossain vaiheessa tulla takapakkii ('PRT some some childhood autists may then get better so that they get along very well as adults whereas some Aspergers then may er regress at some point backpedal', lines 5-8);

4 mutta tota autismi johtuu ilmeisestikin useista tekijöistä et semmosta niin kun: tiedeyhteisön konsensusta ei oo et mistä se tulee ('but er autism results apparently from several factors PRT there is no sort of PRT er: scientific community's consensus about where it comes from', lines 9-12); and

5 mutta tota perimä on yks tekijä siinä ('but er the genotype is one factor in it', lines 12-13).

The first spoken sentence of the extract is the last unit of the preceding speech paragraph. The second one starts a new speech paragraph. The sentences are thematically related to each other, but the beginning of the second sentence marks a change of perspective. First the speaker states that the prognosis of Asperger Syndrome is, generally speaking, better than that of autism. Then she continues that despite the prognosis, individual differences are remarkable. The onset ([mut]) of the second spoken sentence is produced 8.3 semitones higher than the onset of the preceding sentence. Figure 1 presents the pitch curve during the production of the second sentence. The mean pitch of the speaker is 176.7 $\mathrm{Hz}$ (pitch range 26.2-286.5 Hz). A dotted line indicates the mean pitch in the figures.

The word mutta ('but') is an adversative-concessive conjunction, which indicates here a change of perspective (ISK 2004: §1103). Thus, both lexical and prosodic means are used for marking the beginning of a new speech paragraph. The role of prosody is however crucial, because a sentence-initial mutta does not necessarily always start a new speech paragraph; the fifth sentence of the extract is a good example of this (cf. analysis below).

The next sentence starts with the particle että ('that'). When this particle occurs in the beginning of a spoken sentence, it indicates that the new sentence is a paraphrase or a conclusion from the preceding one (ISK 2004: §1032). This sentence starts 5.4 semitones lower than the preceding sentence. Consequently, it belongs to the same speech paragraph. Here, too, two parallel resources - prosody 


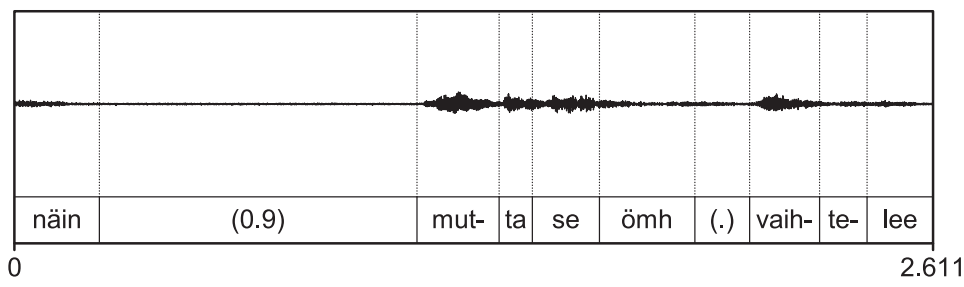

Time (s)

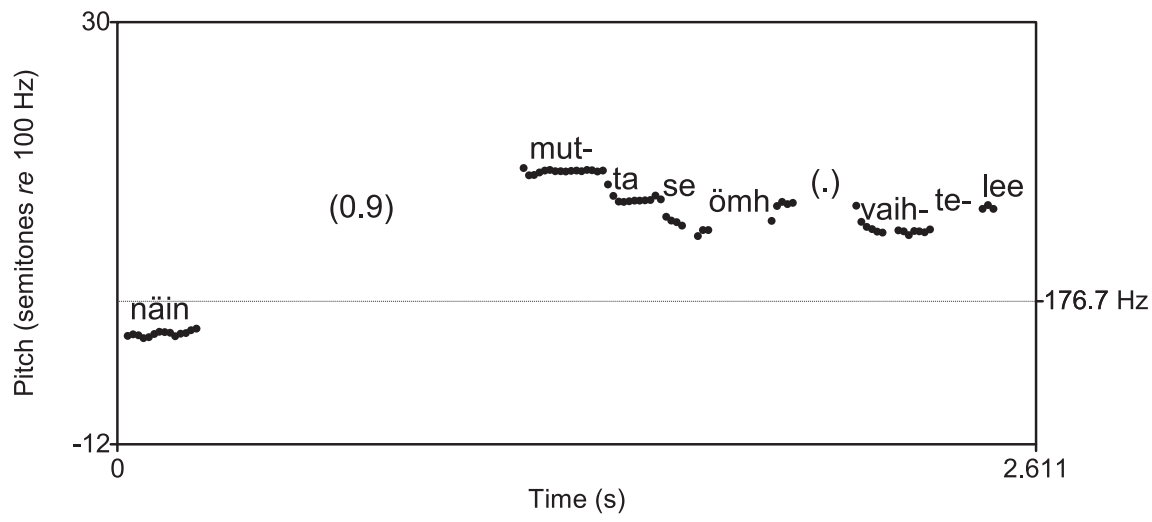

Fig. 1: Pitch curve during the end of the 1st utterance and the entire 2nd utterance (example [1])

and a discourse connective - are used to signal the relationship between the spoken sentences, i.e., the fact that they belong to the same topical unit (cf. Figure 2).

The fourth sentence starts again with the adversative-concessive conjunction mutta ('but') indicating a new perspective (ISK 2004: §1103): the speaker has been talking about the differences between autism and Asperger syndrome, and now she moves on to the causes of autism. The onset of the spoken sentence is produced 2.3 semitones higher than the onset of the preceding sentence. Thus, there is a PR here. Here, too, the change of paragraph is indicated both prosodically and lexically. The pitch level carried by the onset is shown in Figure 3.

Also the fifth spoken sentence starts with the conjunction mutta. Differently from the preceding occurrences of mutta, the conjunction does not indicate a change of perspective here. The fifth sentence is closely related to the fourth one. The conjunction mutta indicates however an adversative-concessive relationship between these sentences (ISK 2004: §1103): even if there is no consensus about the origin of autism within the scientific community, it is known that the genotype is one relevant factor. Consequently, as there is no change of perspective, and as the sentences are closely related to each other despite the presence of the 


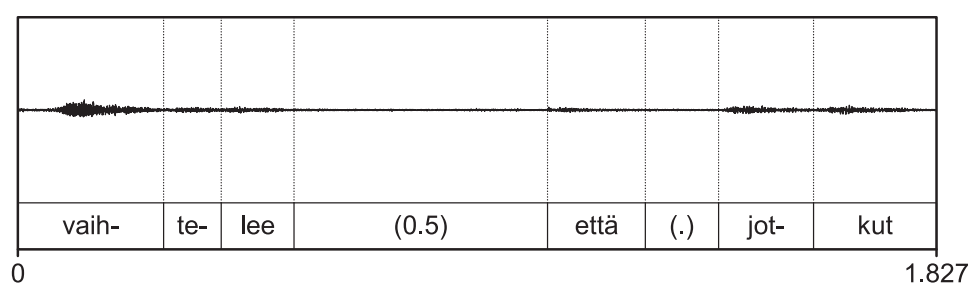

Time (s)

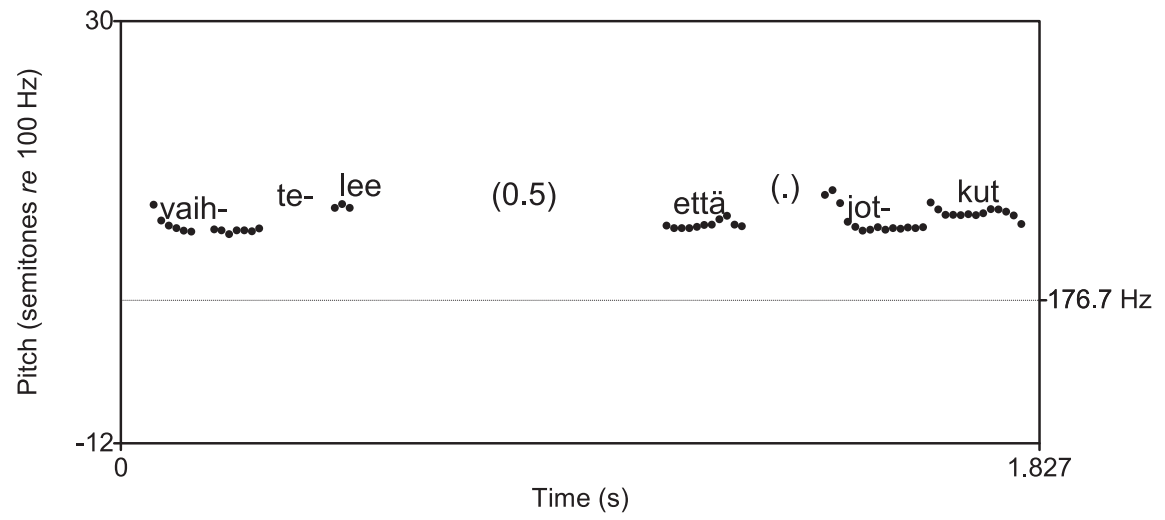

Fig. 2: Pitch curve during the end of the 2nd utterance and the beginning of the 3rd utterance (example [1])

adversative-concessive conjunction, it is logical that these units belong to the same speech paragraph. Indeed, there is no PR here, because the fifth spoken sentence starts 3.4 semitones lower than the fourth one (cf. Figure 4).

The second example has been drawn from the male informant's speech. The man is a representative of The Finnish Federation of Hard of Hearing (Kuuloliitto). He is visiting a meeting of a club for deafened people and telling them about the Federation.

(2)

$1>^{\circ}$ voiko istua $^{\circ}<(2.0)$ oikee hyvää iltaa vaan kaikille can I sit down very good evening (PRT) everyone

2 (1.0) parempi on istua kunto näyttää niin en oo sitten it is better to sit down the condition shows so that I will be

3 (0.7) sen enempää tulkkauksen tiellä kun (1.6) tän dianeither in the way of the interpretation nor in the way of this slide-

4 (1.6) videotykin näytönkään tiellä (1.4) ihan ensialkuun data projector's screen first of all 


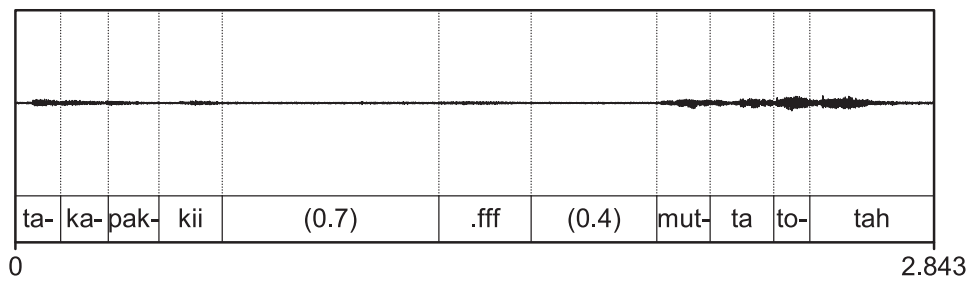

Time (s)

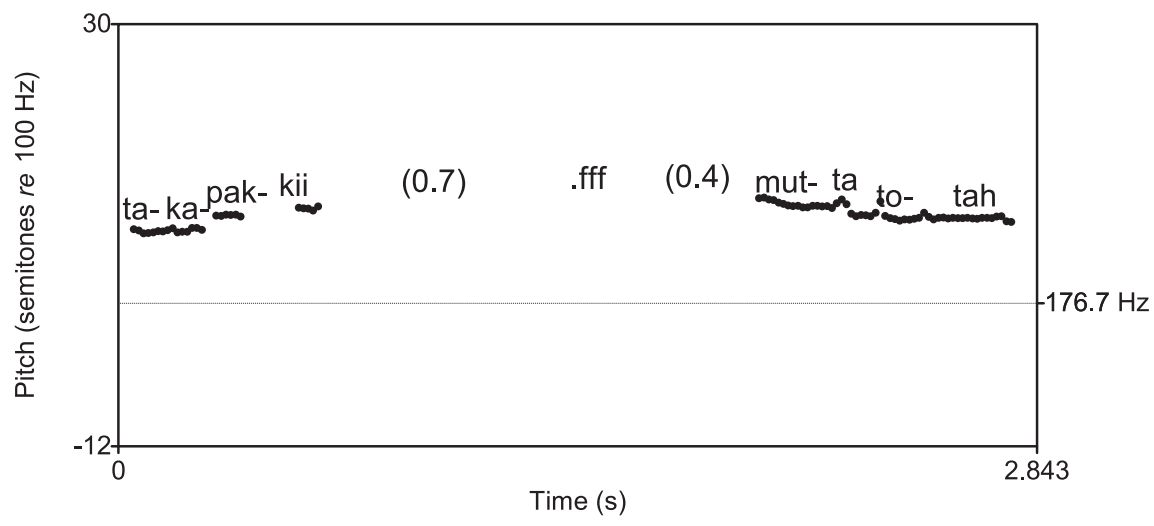

Fig. 3: Pitch curve during the end of the 3rd utterance and the beginning of the 4th utterance (example [1])

5 niin öh (0.7) tosi paljon kiitoksia (0.7) siitä että

er thank you very much for the fact that

6 (1.5) saan olla täällä tänä iltana teiän kanssanne

I can be here tonight with you

7 (1.6) olin ${ }^{8}$ olin tosi otettu kun minua tänne

I was I was very pleased when I was

8 pyydettiin (1.2) eli (0.5) tulen tulen hyvin mielelläni

asked to come here in other words I come I come with pleasure

9 (1.5) katsomaan minkälaista teiän (0.8) toiminta on to see what kind of activity you have here

10 ja (1.7)

and

8 This cut-off is considered to belong to the same spoken sentence with what will follow, because it belongs to the same intonation unit. In fact, it could be defined as a repetition of a word rather than as a cut-off. 


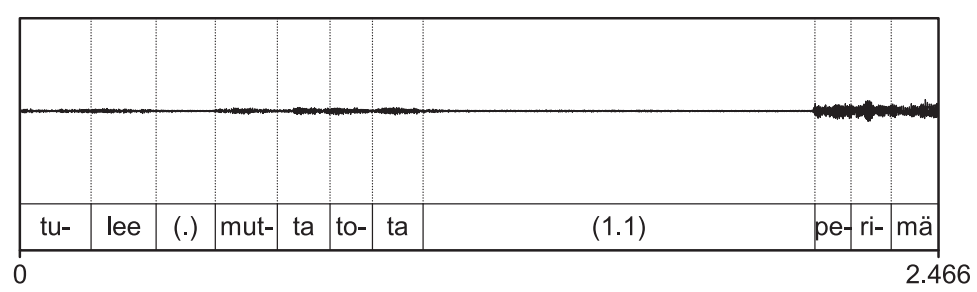

Time (s)

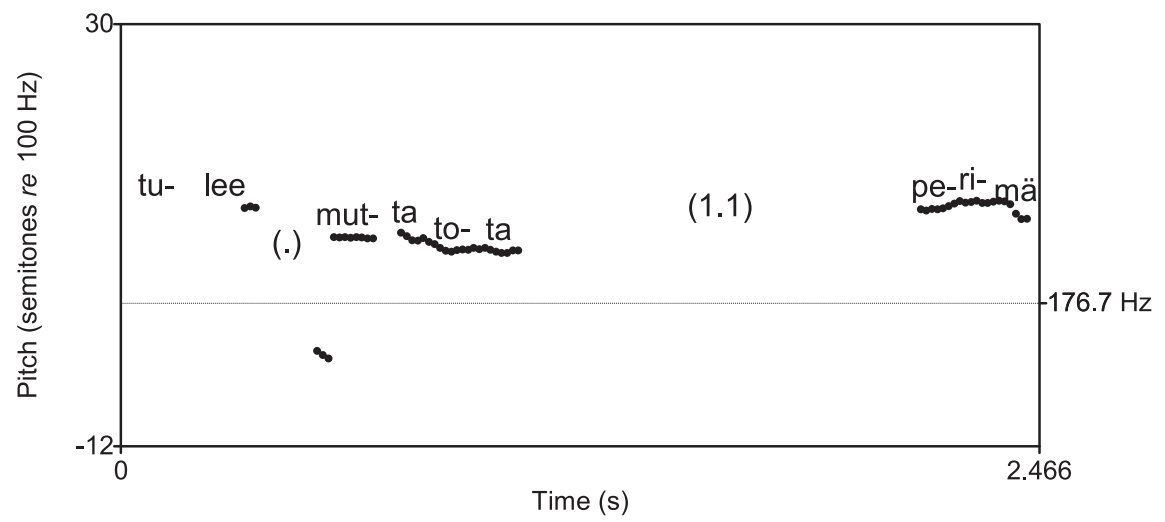

Fig. 4: Pitch curve during the end of the 4th utterance and the beginning of the 5th utterance (example [1])

The example consists of five spoken sentences:

1 voiko istua ('can I sit down', line 1)

2 oikee hyvää iltaa vaan kaikille ('very good evening PRT to everyone', line 1);

3 parempi on istua kunto näyttää niin en oo sitten sen enempää tulkkauksen tiellä kun tän dia- videotykin näytönkään tiellä ('it is better to sit down the condition shows so I will be neither in the way of the interpretation nor in the way of this slide- data projector's screen', lines 2-4);

4 ihan ensialkuun niin öh tosi paljon kiitoksia siitä että saan olla täällä tänä iltana teiän kanssanne ('first of all er thank you very much for the fact that I can be here tonight with you', lines 4-6);

5 olin olin tosi otettu kun minua tänne pyydettii eli tulen tulen hyvin mielelläni katsomaan minkälaista teiän toiminta on ja ('I was I was very pleased when I was asked to come here in other words I come I come with pleasure to see what kind of activity you have here and', lines 7-10).

The first spoken sentence, voiko istua ('can I sit down', line 1), is a question. It ends the preceding speech paragraph, which is the opening sequence of the talk 

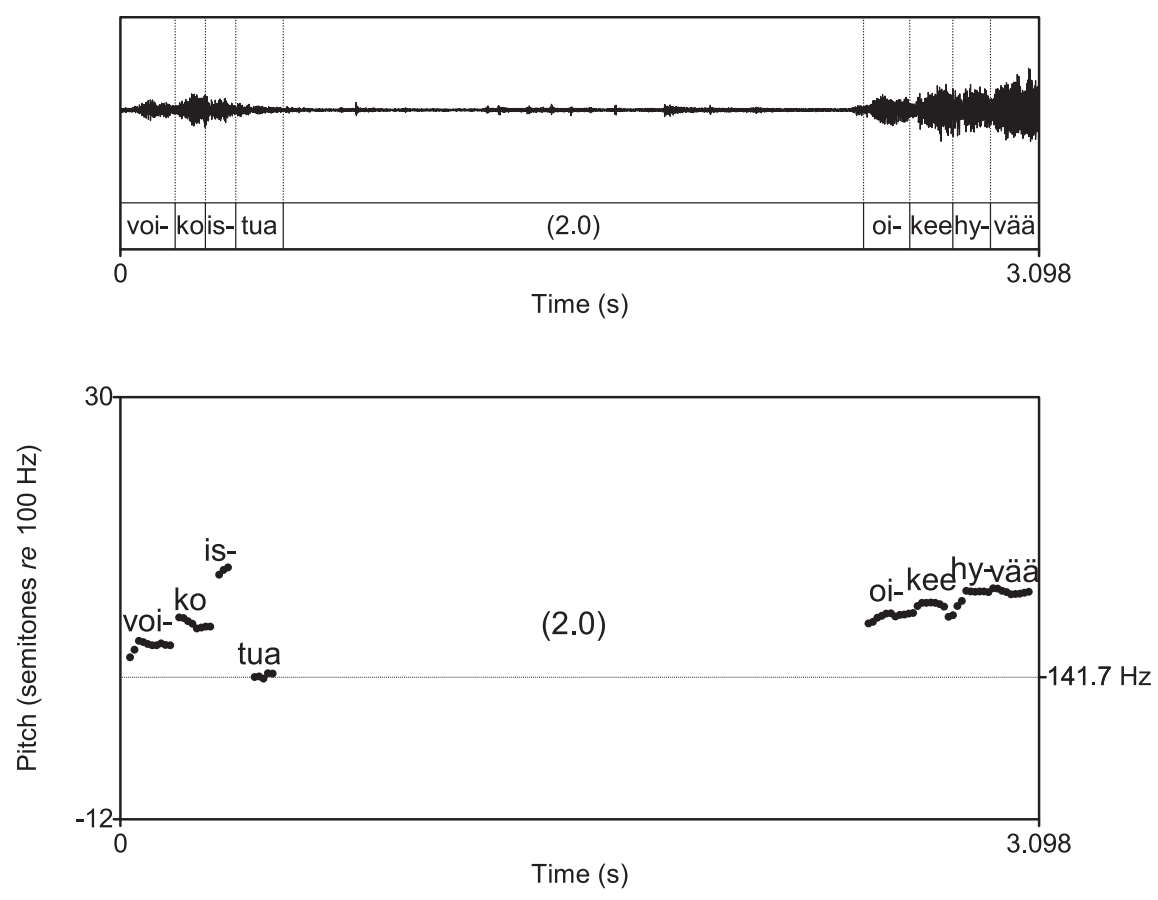

Fig. 5: Pitch curve during the 1st utterance and the beginning of the 2nd utterance (example [2])

(Schegloff 2002). The second spoken sentence is a greeting, which begins with the intensifying particle oikeen ('very', ISK 2004: §854). It starts a new speech paragraph. (The speaker has already greeted the audience once in the opening sequence, but he repeats the greeting in the second speech paragraph.) The onset ([oi]) of the spoken sentence is produced 3.0 semitones higher than the onset of the preceding sentence (cf. Figure 5). The speaker's mean pitch is $141.7 \mathrm{~Hz}$ (pitch range: $51.8-275.4 \mathrm{~Hz})^{9}$

The next spoken sentence also starts a new paragraph: its onset ([pa]) is produced 1.8 semitones higher than the onset of the first sentence (cf. Figure 6). The beginning of a new speech paragraph is not really indicated by lexical means in these two cases. That is, the words oikeen ('very') and parempi ('better') do not imply a new beginning as such. The implication of a new paragraph is related to

9 In these data, one often hears the print interpreters tapping away at their computers during the pauses. This unfortunately causes small disturbances in the pitch curves. 


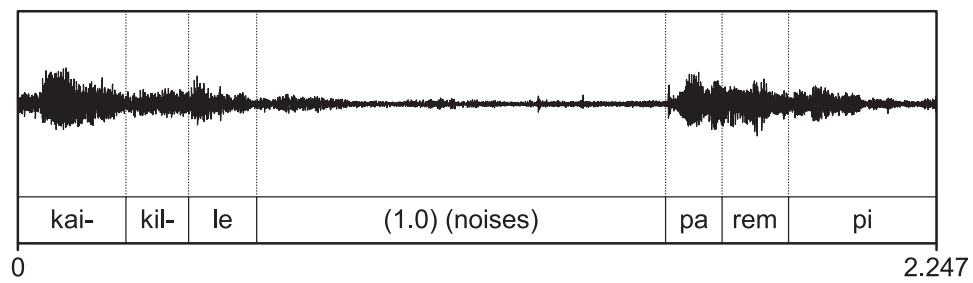

Time (s)

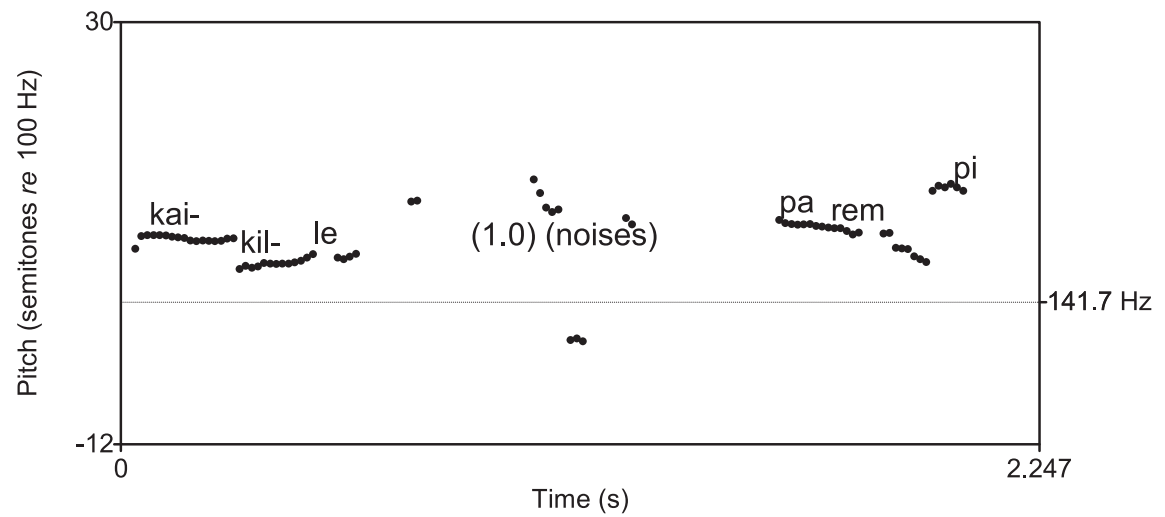

Fig. 6: Pitch curve during the end of the 2nd utterance and the beginning of the 3rd utterance (example [2])

the action of the speaker: in the first spoken sentence, the speaker greets the listeners, and in the second one he explains why he has chosen to sit instead of standing. ${ }^{10}$ As these two spoken sentences constitute two independent illocutionary acts (Austin 1975), it seems natural that they also belong to two different speech paragraphs.

The fourth spoken sentence begins with a PR carried by the particle ihan ('quite'). The particle acts here as an intensifier of the following adverb ensialkuun ('to start with', ISK 2004: §854). In this context, the expression ihan ensialkuun ('first of all') is used as a discourse connective referring to the structure of the talk

10 The sequence kunto näyttää ('the condition shows', lines 1 and 2) is a parenthesis, that is, an increment occurring inside a syntactic construction and interrupting this construction without being syntactically part of it (Duvallon and Routarinne 2005; ISK 2004: §1071). The sequence constituting the parenthesis is also grammatically illogical here, but its approximate meaning can be deduced from the larger discursive context. 


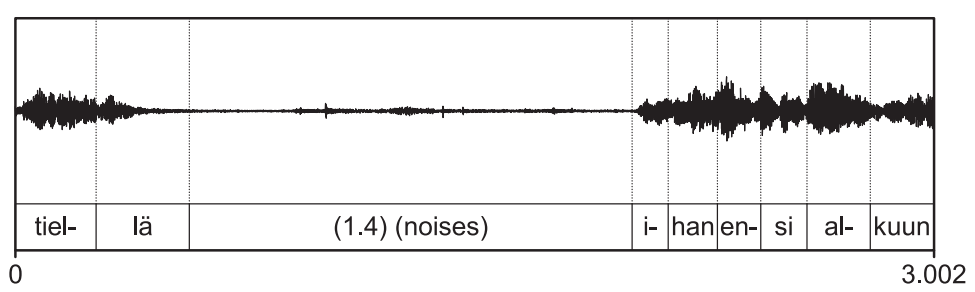

Time (s)

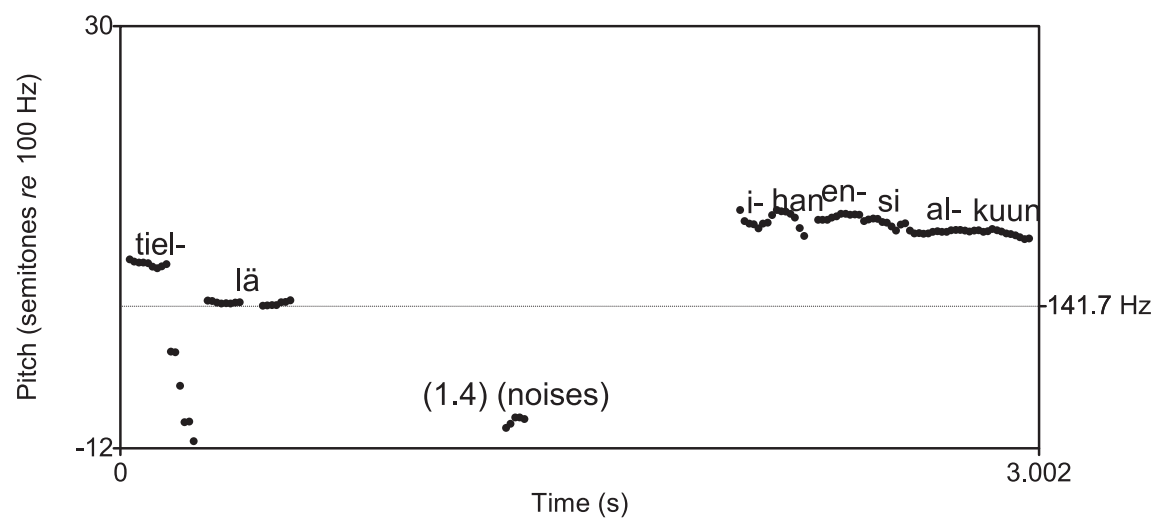

Fig. 7: Pitch curve during the end of the 3rd utterance and the beginning of the 4 th utterance (example [2])

(ISK 2004: §650, §820): it indicates that the speaker starts with something, and after that he will move on to something else. The connective also implies that a new speech paragraph is about to start. The onset of the spoken sentence ([i]) is produced 0.7 semitones higher than the onset of the preceding sentence (cf. Figure 7).

The last spoken sentence of the extract starts with the verb olin (olla: 'to be' $\rightarrow$ olin: 'I was'). Its onset is produced 5.2 semitones lower than the onset of the fourth spoken sentence (cf. Figure 8). Consequently, there is no PR here, and the sentences belong to the same speech paragraph. This seems natural, because there is no topical shift between the spoken sentences. First the speaker thanks the participants for the invitation to give a talk; then he adds that he was very pleased about being invited.

Example (3) presents another occurrence of the PR in the presentation of the male speaker. This passage also comes from the beginning of the presentation, when the speaker is explaining practical things related to his talk. The speaker has just stated that he has two slide shows. In the first spoken sentence he adds 


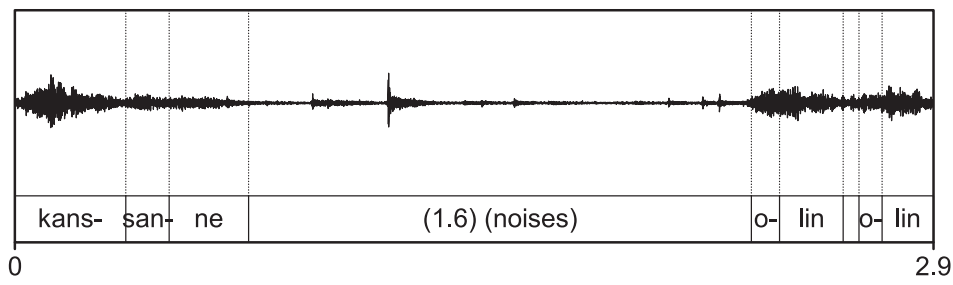

Time (s)

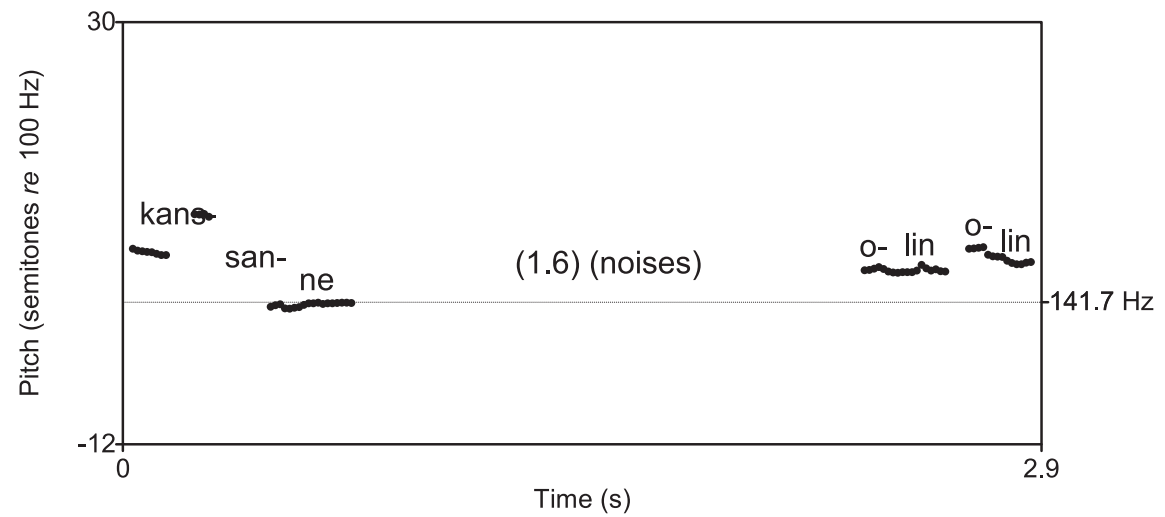

Fig. 8: Pitch curve during the end of the 4th utterance and the beginning of the 5 th utterance (example [2])

that one of the two computing specialists who are present will help him to switch from one presentation to the other when the time comes.

(3)

1 Ja sitten varmaan Maarit tai Pena neuvoo minulle, että and then I guess Maarit or Pena will show me

2 mitenkä vaihdetaan siihen toiseen (1.5) diaesitykseen. how to switch to the other slide show

3 (1.5) itse en ole mikään (1.6) tekniikan ihmelapsi (1.4)

I am not a child prodigy of technology myself

4 sen verran olen investoinu et $t^{\circ} \ddot{a}^{\circ}(1.7)$ poika neuvo but that much I have invested that my son advised me

5 ostamaan tommosen MUISTItio kun $^{\circ}$ (1.8) ja: hän sano että to buy that kind of a USB flash drive a:nd he said that

6 siihen mahtuu (0.6) koko sinun elämäsi (0.6) your whole life fits into it 

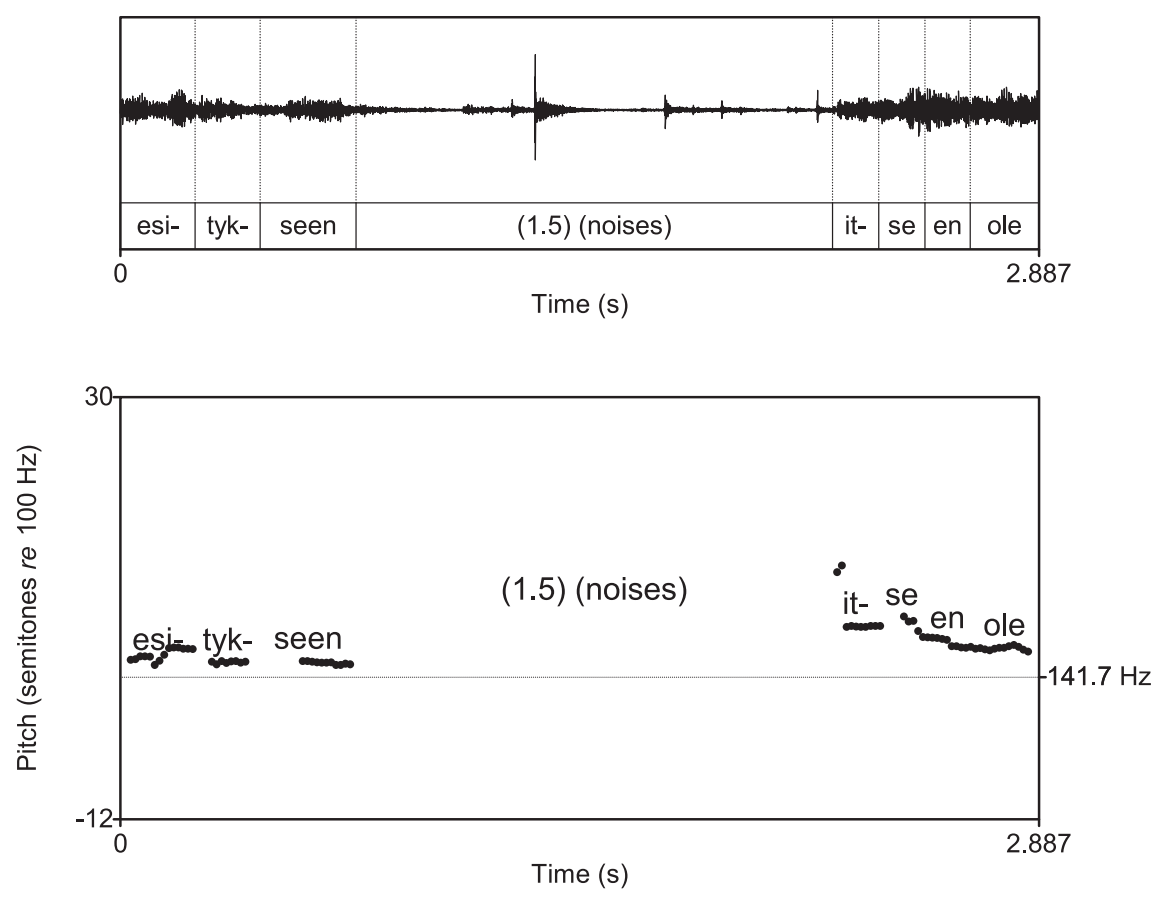

Fig. 9: Pitch curve during the end of the 1st utterance and the beginning of the 2nd utterance (example [3])

The extract includes four spoken sentences:

1 ja sitten varmaan Maarit tai Pena ${ }^{11}$ neuvoo minulle, että mitenkä vaihdetaan siihen toiseen diaesitykseen ('and then I guess Maarit or Pena will show me how to switch to the other slide show', lines 1 and 2)

2 itse en ole mikään tekniikan ihmelapsi ('I am not a child prodigy of technology myself', line 3)

3 sen verran olen investoinu että poika neuvo ostamaan tommosen muistitikun ('that much I have invested that my son advised me to buy that kind of a USB flash drive', lines 4 and 5)

4 ja hän sano että siihen mahtuu koko sinun elämäsi ('and he said that your whole life fits into it', lines 5 and 6 )

The first spoken sentence is the last sentence of the preceding speech paragraph. The second spoken sentence constitutes an own speech paragraph. Its onset is

11 The names have been changed. 

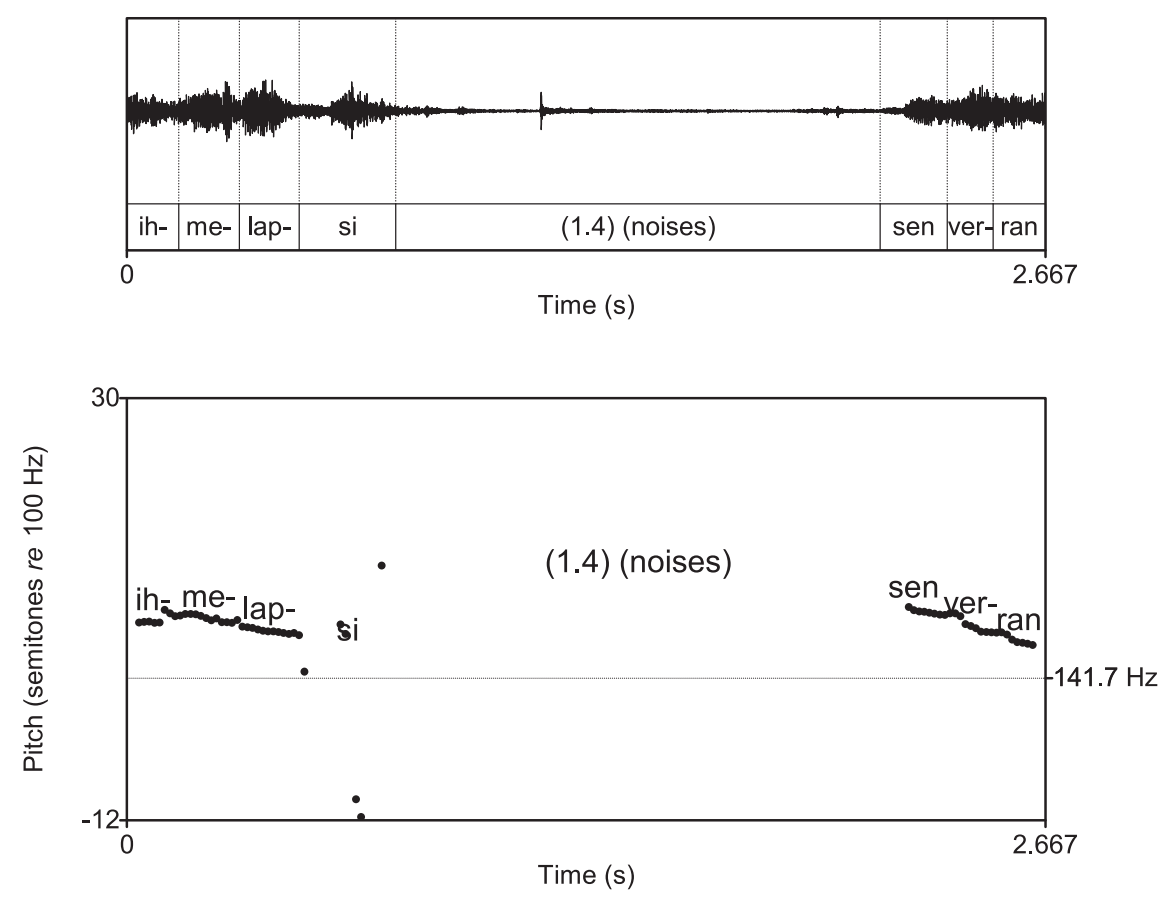

Fig. 10: Pitch curve during the end of the 2nd utterance and the beginning of the 3rd utterance (example [3])

produced 4.2 semitones higher than the onset of the first spoken sentence (cf. Figure 9).

The word itse that starts the spoken sentence carries a contrastive function here (ISK 2004: §768). It marks a contrast between the speaker himself and the two computing specialists ("Maarit" and "Pena", line 1) who have been mentioned in the preceding speech paragraph. The PR carried by itse emphasizes the contrastive function of the word: "These two persons are computing specialists, whereas I am not".

The third spoken sentence starts a new speech paragraph. It starts with the adverb sen verran ('that much') which intensifies here the following clause starting with the conjunction että ('that') (ISK 2004: §1160). The PR emphasizes here the change of perspective indicated by the construction sen verran - että. Indeed, the construction carries an adversative-concessive function that could be compared with that of the conjunction mutta ('but') starting the second and the fourth spoken sentences in example (1) (ISK 2004: §1103). The onset ([sen]) of this 


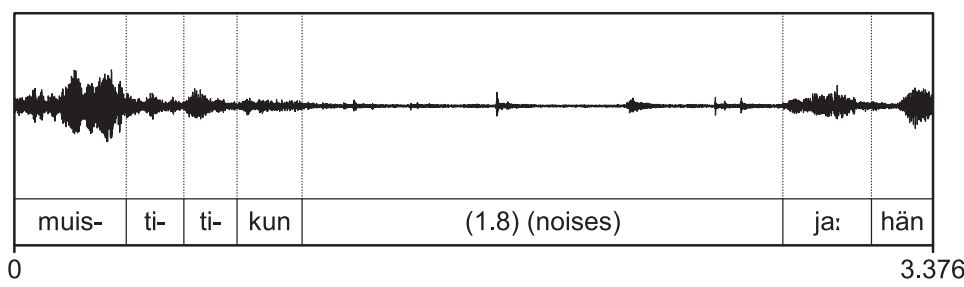

Time (s)

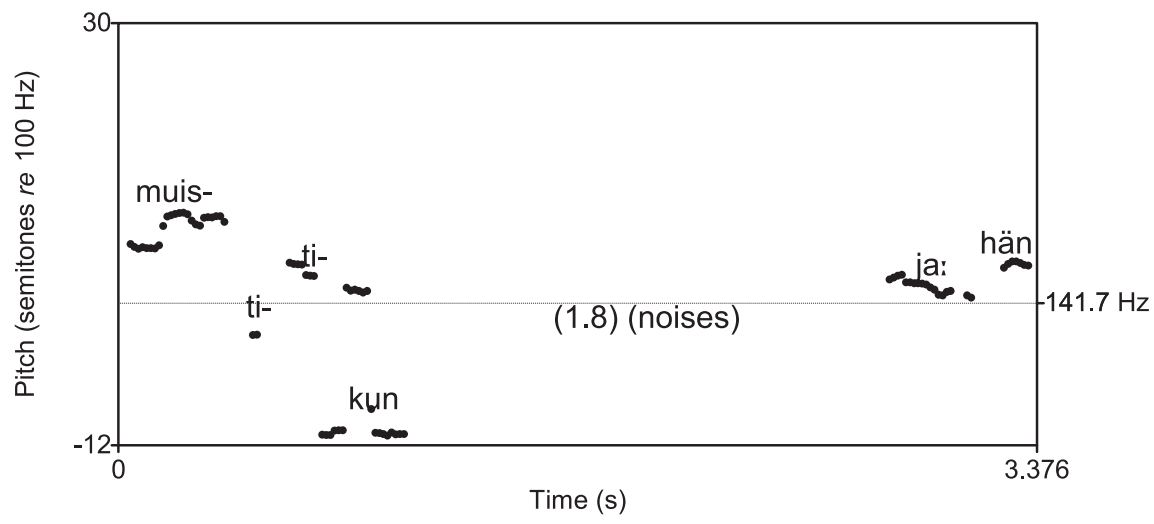

Fig. 11: Pitch curve during the end of the 3rd utterance and the beginning of the 4th utterance (example [3])

sentence is produced 1.6 semitones higher than the onset of the preceding sentence (cf. Figure 10).

The fourth spoken sentence starts with the particle $j a$ ('and'). It is produced 4.9 semitones lower than the onset of the preceding sentence (cf. Figure 11). Consequently, there is no PR here. The particle $j a$ is a typical additive discourse connective which links spoken sentences to each other (ISK 2004: §804). Therefore it seems logical that there is no change of speech paragraph at this point. Thus, here too, both lexical and prosodic means are used to indicate the relationship between the sentences.

It is also noteworthy that the particle $j a$ is lengthened. ${ }^{12}$ According to Morel (2010: 22), the lengthening of a syllable sometimes constitutes a disfluency marker: it allows the speaker to keep the vocal tract occupied, and prevents in this manner the creation of an irrelevant intonation boundary that could mislead

12 The lengthening is marked with a colon in the transcription. 
the listener. ${ }^{13}$ Morel's remark seems to apply here, because if the speaker did not mark the disfluency with a lengthened syllable or another vocalization, there would probably be a pause. At least in my data, the pitch level tends to go up after a pause. This, in turn, could easily create a PR and alter the relationship between the sentences.

As the examples presented in this section have shown, the PR phenomenon exists also in Finnish, and its occurrences indicate a change of speech paragraph. This is in line with Aho and Yli-Luukko's (2005: 210) findings according to which the beginning of a major intonation unit usually manifests itself as a rise in pitch. The next section will discuss the ways in which the PR is taken into account in the written target text.

\section{Printed output}

The results of this study suggest that the PR constitutes a clear sign of the beginning of a new speech paragraph. As the simultaneous interpreters in the study by Nafa Waasaf (2007), the print interpreters in the present data corpus treat the high pitch as a mark of an initial paragraph boundary. Indeed, when the PR occurs in speech, it causes a change of paragraph in the written output in $91.7 \%$ of the cases. Example (4) presents the printed output of the extract of speech given in example (1).

(4)

1 Mutta se vaihtelee - jotkut saattavat kuntoutua hyvinkin

2 pärjääviksi aikuisiksi ja jotkut saattavat taantua. 3

4 Autismi johtuu useista tekijöistä. Konsensusta ei ole,

5 mutta perimä on 1 tekijä.

Translation:

1 But it varies - some may get better so that they get

2 along very well as adults and some may regress.

3

4 Autism results from several factors. There is no

5 consensus, but the genotype is 1 factor.

13 Morel's (2010) data come from naturally occurring French conversations. 
A paragraph division is marked in these data with a blank line. This type of paragraph division is sometimes called a "technical paragraph" (Korpela 2004-2012). As the extract shows, there are two written text paragraphs in this example. The changes of (sub)topics coincide with paragraphs in the spoken source text and in the written target text: the PRs occurring in the spoken input lead to paragraph divisions in the written output. The first spoken sentence of the extract, which is the last sentence of the preceding speech paragraph, is completely reduced by the print interpreter. The second spoken sentence, which begins a new speech paragraph, also starts a written paragraph (line 1). In the beginning of the second paragraph (line 4), the conjunction mutta ('but') that carries the PR has been omitted. This is quite frequent, which brings forward the discursive function of the PR: the phenomenon does not work to emphasize the word that carries it, but it acts as a discourse-structuring marker. The reduction of sentence-initial particles may also be related to their different uses in speech and writing.

In all, the spoken source texts of the data include 33 speech paragraphs. ${ }^{14}$ The number of the written text paragraphs is $60 .{ }^{15}$ The fact that the number of the written paragraphs is almost twice as big as that of the speech paragraphs implies that, on average, the text paragraphs are also significantly shorter than the speech paragraphs. Consequently, the findings of this study are not in line with those of Brown et al. (1980: 26) according to which speech paragraphs are typically much shorter than written paragraphs. This is probably related to the special character of PI situations - i.e., the fact that the presentation of the printed output is supposed to correspond to the spoken input as closely as possible. The remarkably large font size used in PI constitutes also a relevant factor, because the printed text presented on the screen would not be legible without frequent paragraph divisions.

Thus, the PR cannot be the only feature that plays a role in indicating discourse boundaries that lead to a paragraph division in the written target text. Indeed, in these data, there seems to be two types of boundaries: "Strong boundaries" occur between two speech paragraphs. These boundaries are prosodically marked with a PR preceded by a pitch movement (fall or rise) and a pause. "Weak boundaries," in turn, occur inside a speech paragraph, and they are prosodically marked only with a sentence-final pitch movement (fall or rise) and a pause, without a PR in the beginning of the next unit. In example (4), there is a strong boundary in both cases, when the interpreter starts a new written paragraph: The

14 There are 17 speech paragraphs in the female informant's speech, and 16 in the male informant's speech.

15 Both parts of the data include 30 written text paragraphs. 
first paragraph (line 1) starts with a PR, and it is preceded by a pause and by a pitch fall in the spoken source text (cf. example [1]). The second one (line 4) also begins with a PR, and the paragraph division is preceded by a pause and a pitch rise.

In my data, the shapes of the prosodic features that typically coincide with the change of paragraph in the printed output seem to be subject to idiolectal variation, but on the idiolectal level, their manifestations are rather regular. In the data concerning the male speaker's presentation, there is almost always (96.7\%) a pitch fall at the end of the spoken sentence preceding the paragraph division in the printed output. This does not seem surprising in the light of previous studies according to which the end of a paragraph-like unit of speech typically carries a low pitch (Aho and Yli-Luukko 2005; Hirvonen 1970; Morel 2010; Wichmann 2000). However, in the female speaker's presentation, a pitch fall precedes the change of paragraph only in less than half of the cases $(40.0 \%)$. A pitch rise in the same position is more frequent (50.0\%) in her speech. This is rather interesting, because as in many other languages, previous studies suggest that sentence-final pitch rise indicates continuity also in Finnish (Hirvonen 1970; Lehtinen 2010; Lyytikäinen 1995; Ogden and Routarinne 2005; Routarinne 2003). However, most of these studies have treated only female speakers. It is also noteworthy that in the female speaker's presentation, the last spoken sentence of the last speech paragraph ends in a pitch fall. Therefore it is possible that even if a pitch rise occurs frequently $(50.0 \%)$ at the end of a paragraph in her speech, it carries a continuative function, too: that is, on the one hand, it indicates the end of a speech paragraph, but on the other hand, it implies that the discourse will still continue.

In addition to a final pitch movement (fall or rise), paragraph divisions of the written target text are usually preceded by a pause in the spoken source text. Aho and Yli-Luukko (2005: 210) have observed that major intonation units usually end in a long pause. According to Morel and Danon-Boileau (1998: 14-15), a pause the duration of which is more than 0.4 seconds works to "homogenize" the preceding unit as a thematic continuum. Therefore it is logical that also print interpreters treat long pauses as signs of thematic boundaries, when they are associated with a sentence-final pitch movement. The mean duration of the pauses causing a paragraph division in the printed output is 2.1 seconds for the male speaker and 0.8 seconds for the female speaker. In the male speaker's case, there is always a pause before a paragraph division, whereas in the female speaker's presentation, the pause is absent in $23.3 \%$ of the cases where the interpreter makes a paragraph division. Thus, the pause is not a necessary feature either.

Table 1 summarizes the prosodic features that typically coincide with a change of paragraph in the printed output: 
Table 1: Prosodic features coinciding with paragraph divisions

\begin{tabular}{lccc}
\hline Prosodic feature & Female speaker & Male speaker & Both speakers \\
\hline Pitch reset & $86.7 \%$ & $96.7 \%$ & $91.7 \%$ \\
Sentence-final pitch movement & $90.0 \%$ & $96.7 \%$ & $93.4 \%$ \\
Pitch fall & $40.0 \%$ & $96.7 \%$ & $68.4 \%$ \\
Pitch rise & $50.0 \%$ & $0.0 \%$ & $25.0 \%$ \\
Pause & $76.7 \%$ & $100 \%$ & $88.4 \%$ \\
Mean duration & $0.8 \mathrm{sec}$ & $2.1 \mathrm{sec}$ & $1.5 \mathrm{sec}$ \\
\hline
\end{tabular}

In addition to the more systematically occurring features presented in Table 1, sometimes there is a slowed speech rate at the end of the preceding paragraph and an accelerated speech rate in the beginning of the new paragraph (Wichmann 2000: 32). Creaky or remarkably quiet voice is also characteristic of the ends of speech paragraphs (Aho and Yli-Luukko 2005).

Often there is a paragraph division in the written target text even in the absence of a speech paragraph boundary. The following example includes one occurrence of this phenomenon. The example consists of the print interpretation of the extract of speech given in example (2).

1 voinko istua?

2

3 Olkein hyvää iltaa vaan kaikille.

4

5 Parempi on istua, Unto näkee, etten oo tulkkauksen tiellä

6 enkä tän diankaan, tän videotykin näytön tiellä.

7

8 Ensi alkuun tosi paljon kiitoksia siitä, että saan olla

9 täällä tänä iltana kanssanne.

11 Olin tosi otettu, kun minua tänne pyydettiin eli tulen

12 hyvin mielelläni.... katsomaan, millaista toimintanne on.

Translation:

1 can I sit down?

2

3 Very good evening to all.

4 
5 It's better to sit down, Unto sees, so that I won't be in the way of the interpretation

6 neither in the way of this slide, this data projector's screen.

8 First of all thank you very much for the fact that I can be

9 here with you tonight.

10

11 I was very pleased when I was asked to come here in other words I come

12 with pleasure. ... to see, what kind of activity you have here.

The beginnings of the three first written paragraphs (lines 3, 5, and 8) of this example match with changes of speech paragraphs. ${ }^{16}$ That is, when the interpreter starts a new written paragraph, there is a strong boundary in the spoken source text. The first written paragraph (line 3) coincides with a PR in the spoken input, and it is preceded by a pause and a pitch fall. The second written paragraph (line 5) also coincides with a PR, and it is preceded by a pause. The preceding spoken sentence however carries a flat pitch, which is exceptional. This atypical intonation is probably related to the fact that the sentence that carries it is a greeting. As the first and the second written paragraphs, the third one (line 8) also coincides with a PR (though the particle ihan carrying the high pitch is omitted), a pause and a pitch fall.

The last paragraph division (line 11), in turn, represents an occurrence where a weak boundary in the spoken source text leads to a change of paragraph in the written target text. There is no PR in the beginning of the spoken sentence starting with the word olin ('I was'), and therefore the spoken sentence belongs to the same speech paragraph than the preceding one, even if there is a paragraph division in the printed output. The new paragraph is however preceded by a pause and a pitch fall. The preceding spoken sentence constitutes a clearly distinct illocutionary act (Austin 1975) in which the speaker expresses his gratitude to the participants. This may explain the fact that there is a paragraph division at this point even if there is no PR in the spoken source text. The next spoken sentence is an explanatory increment. It is therefore closely related to the preceding spoken sentence from the topical viewpoint. It does not however really belong to the same action, because "the act of thanking" has already been accomplished in the preceding sentence.

16 The first sentence (line 1) is the last sentence of the preceding paragraph in the spoken input as well as in the written output. 
Studies in conversation analysis have shown that some actions belong more closely together than others (e.g., Couper-Kuhlen 2004; Ford 2002). Indeed, the action of the speaker seems to play a role in the structuring of the discourse also in my data. There is an example of this in the same extract (cf. example [2]): the second spoken sentence is an explanation of why the speaker has chosen to sit instead of standing. The spoken sentences constitute two independent illocutionary acts (Austin 1975), and they belong to two different paragraphs both in the spoken input and in the printed output. The difference between the case described above (act of thanking + explanatory increment) is however that in addition to constituting distinct illocutionary acts, these two spoken sentences are topically unrelated. Therefore it is logical that - differently from the case of topically related spoken sentences - there is a PR in the beginning of the second sentence.

Another interesting feature here is the mistake the interpreter makes. In the spoken source text (example [2]), the speaker says kunto näyttää ('condition shows', line 2), but in the written target text (example [5]), it is interpreted Unto näkee ('Unto sees', line 5). The speaker probably means to say self-ironically that he prefers to sit down because of his (pretended) poor physical condition. At first, the meaning of this remark is however not obvious, because it is topically disconnected with regard to the surrounding context: in the frame construction, the speaker is worried about obstructing the view of the listeners, whereas in the parenthesis he suddenly jumps to his own physical condition. According to Drew (1997), this type of topical discontinuity is a common cause of misunderstandings. Indeed, in this example, the interpreter seems to adapt the contents of the parenthesis to the topic of the frame construction, which leads to a mistake in the written target text. In addition to the topical discontinuity, the parenthesis is grammatically illogical, and it is produced with an accelerated speech rate and at a lowered pitch level (cf. example [2]). These features may also make the parenthesis more difficult to understand. On the other hand, the change of intonation often constitutes a signal of a change of modality (Nuolijärvi and Tiittula 2010). In this context, the change of intonation could be interpreted as a sign of irony.

The last example presents a case where a PR does not lead to a paragraph division in the written target text. The extract given here is the printed output of example (3).

(6)

1 Ja sitten varmaan Maarit tai Pena neuvoo minulle,

2 mitenkä vaihdetaan sühen toiseen diaesitykseen.

3

4 Itse en ole mikään tekniikan ihmelapsi. Sen verran olen 
5 investoinut, että poika neuvo ostamaan tollasen

6 muistitikun.

7

8 Hän sanoi,e ttä siihen mahtuu koko sinun elämäsi.

Translation:

1 and then I guess Maarit or Pena will show me how to switch

2 to the other slide show

3

4 I am not a child prodigy of technology myself. That much I have

5 invested that my son advised me to buy that kind of a

6 USB flash drive.

7

8 a:nd he said that your whole life fits into it

The spoken source text of this extract includes two PRs: the first one is carried by the word itse ('myself', line 4), and the second one by the expression sen verran ('that much', line 4). Even if the first spoken sentence constitutes its own speech paragraph in the spoken input, it does not constitute its own written paragraph in the printed output. This is probably related to the fact that the written text paragraph is so short at the moment of the PR: when the PR occurs, there is only one sentence in the written target text, whereas the mean length of a written paragraph is 2.1 sentences for this interpreter. ${ }^{17}$ Indeed, in all the rare cases $(8.3 \%)$, where a PR does not lead to a paragraph division in the printed output, the written paragraph is briefer than a mean paragraph of the interpreter in question at the moment of the PR. Thus, the length of the written paragraph at the moment of the PR also seems to constitute a relevant factor when considering the places of paragraph divisions. On the other hand, long speech paragraphs tend to be divided into several written paragraphs.

In example (6), the fact that the PR occurring in the beginning of the third spoken sentence does not cause a paragraph division may also be related to the nature of the relationship between the sentences: in this context, the PR emphasizes the change of perspective indicated by the adversative-concessive construction sen verran - että ('that much - that') (ISK 2004: §1160). In the second spoken sentence, the speaker states that he is not a computer specialist himself. In the third spoken sentence, he adds that he has however bought a USB flash drive,

17 For the female speaker's print interpreter, the corresponding value is 3.7 sentences. The value has been calculated on the basis of the number of spoken sentences included in the written output. 
because his son advised him to do so. Thus, despite the change of perspective and the beginning of a new speech paragraph, there is a clear topical connection between the spoken sentences.

On the other hand, there is a paragraph division before the fourth spoken sentence (line 8), even if there is only a weak boundary at this point. This results probably from the fact that there was no paragraph division before the preceding spoken sentence, despite the presence of a strong boundary. If the written interpretation of this spoken sentence was also included in the same text paragraph, the paragraph would exceed this interpreter's mean paragraph length (2.1 sentences). The fact that the second written paragraph starts with the anaphoric pronoun hän ('he', line 8) referring to poika ('son', line 5), appearing before the paragraph division, creates an explicit link between the spoken sentences. This may facilitate the insertion of a paragraph division at this point without compromising the structural coherence of the written target text.

\section{Conclusions}

One of the main objectives of this study has been to show that the PR phenomenon can be found also in Finnish data. Aho and Yli-Luukko (2005) had already observed that a raised pitch level of the onset is typical of the beginnings of major intonation units. The present study shows that the raised pitch level is a systematically occurring feature that can be used as a fundamental criterion when determining the limits of speech paragraphs also in Finnish data.

The results of this study show that the PR constitutes a prosodic sign that almost always (91.7\%) leads to a paragraph division in the written target text. This implies that the interpreters treat speech paragraphs as topical units, and that the PR plays an important role in the structuring of discourse. The number of written paragraphs is however nearly twice as big as that of the speech paragraphs. This implies that the PR is not the only feature that plays a role in indicating boundaries leading to paragraph divisions in the written target text. Therefore it would be an oversimplification to claim that an initial boundary of a written text paragraph constitutes the "written equivalent" of the PR of speech. Indeed, two types of prosodic boundaries coinciding with the changes of written paragraphs can be distinguished in these data: strong boundaries and weak boundaries.

In the rare cases $(8.3 \%)$ where a pitch reset does not lead to a paragraph division, the length of the written paragraph is clearly below the average paragraph length of the interpreter in question at the moment of the pitch reset. On the other hand, long speech paragraphs are typically divided into several written para- 
graphs. Sometimes a change of written paragraph may be used to emphasize a limit between two independent actions (Austin 1975; Couper-Kuhlen 2004).

The process of interpreting is also reflected in the structure of the printed output. According to Brown et al. (1980: 26), speech paragraphs tend to be much shorter than written text paragraphs. This is however not the case in the PI data. This is probably related to the special nature of the PI situations.

The study shows that print interpreters take into account the PR phenomenon without being aware of it. In the future, it could also be added to their education in order to make the use of prosodic means even more effective. Awareness of the existence of the PR may help the print interpreters to orient to changes of speech paragraphs. This may contribute to a better correspondence between the spoken source text and the written target text. Awareness of the existence of the paragraph intonation may also lighten interpreters' cognitive burden and lead in this way to a more efficient process of interpreting.

\section{Appendix: conventions of transcription}

Duration of a pause (indicated in tenths of a second)

$><$

Micropause (duration less than 0.2 seconds)

/ /

Accelerated speech rate

\# \#

Raised pitch level

o o

Creaky voice

MUISTI

Quiet voice

kun: $\quad$ Lengthening of a syllable

.fff Audible inhalation through the nose

dia- Interrupted word

Falling pitch

Flat pitch

Rising pitch

\section{Abbreviations}

PRT Particle

\section{References}

Aho, Eija \& Eeva Yli-Luukko. 2005. Intonaatiojaksoista [About intonation units]. Virittäjä 2(2005). 201-220. 
Austin, John Langshaw. 1975. How to do things with words. Oxford: Oxford University Press.

Barth-Weingarten, Dagmar. 2009. When to say something - Some observations on prosodicphonetic cues to the placement and types of responses in multi-unit turns. In Dagmar Barth-Weingarten, Nicole Dehé \& Anne Wichmann (eds), Where prosody meets pragmatics, 143-181. Bingley: Emerald.

Barth-Weingarten, Dagmar. 2011. The fuzziness of intonation units: Some theoretical considerations and a practical solution. InLiSt - Interaction and Linguistic Structures 51. http://www.inlist.uni-bayreuth.de (accessed 18 January 2014).

Boersma, Paul \& David Weenink. 2012. Praat: Doing phonetics by computer, version 5.3.16. http://www.praat.org (accessed 18 January 2014).

Brazil, David, Malcolm Coulthard \& Catherine Johns. 1980. Discourse intonation and language teaching. London: Longman.

Brown, Gillian, Karen L. Currie \& John Kenworthy. 1980. Questions of intonation. London: Croom Helm.

Chafe, Wallace. 1980. The deployment of consciousness in the production of narrative. In Wallace Chafe (ed.), The pear stories: Cognitive, cultural and linguistic aspects of narrative production, 9-50. Norwood: Ablex.

Chafe, Wallace. 1994. Discourse, consciousness, and time. The flow and displacement of conscious experience in speaking and writing. Chicago \& London: The University of Chicago Press.

Couper-Kuhlen, Elizabeth. 1986. English prosody. London: Edward Arnold.

Couper-Kuhlen, Elizabeth. 2004. Prosody and sequence organization in English conversation. The case of new beginnings. In Elizabeth Couper-Kuhlen \& Cecilia E. Ford (eds), Sound patterns in interaction, 335-376. Amsterdam \& Philadelphia: John Benjamins.

Croft, William. 1995. Intonation units and grammatical structure. Linguistics 33. 839-882.

Cruttenden, Alan. 1986. Intonation. Cambridge: Cambridge University Press.

Crystal, David. 1969. Prosodic systems and intonation in English. Cambridge: Cambridge University Press.

Drew, Paul. 1997. "Open” class repair initiators in response to sequential sources of troubles in conversation. Journal of Pragmatics 28. 69-101.

Du Bois, John W. \& Stephan Schuetze-Coburn. 1993. Representing hierarchy: Constituent structure for discourse databases. In Jane A. Edwards \& Martin D. Lampert (eds), Talking data: Transcription and coding methods for language research, 221-260. Hillsdale: Lawrence Erlbaum.

Duvallon, Outi \& Sara Routarinne. 2005. Parenthesis as a resource in the grammar of conversation. In Auli Hakulinen \& Margret Selting (eds), Syntax and lexis in conversation: Studies on the use of linguistic resources in talk-in-interaction, 45-74. Amsterdam \& Philadelphia: John Benjamins.

Ford, Cecilia E. 2002. Denial and the construction of conversational turns. In Joan Bybee \& Michael Noonan (eds), Complex sentences in grammar and discourse, 61-78. Amsterdam \& Philadelphia: John Benjamins.

Helasvuo, Marja-Liisa. 2001. Syntax in the making: The emergence of syntactic units in Finnish conversation. Amsterdam \& Philadelphia: John Benjamins.

Helasvuo, Marja-Liisa. 2003. What can intonation tell us about constituency? In Tsuyoshi Ono, Toshihide Nakayama \& Hongyin Tao (eds), Recent studies in empirical approaches to grammar, 20-34. Santa Barbara: University of California. 
Hirvonen, Pekka. 1970. Finnish and English communicative intonation. Turku: University of Turku.

livonen, Antti. 1998. Intonation in Finnish. In Daniel Hirst \& Albert Di Cristo (eds), Intonation systems. A survey of twenty languages, 311-327. Cambridge: Cambridge University Press.

livonen, Antti \& Reijo Aulanko (eds). 2001. Fonetiikan peruskäsitteitä [Basic concepts of phonetics]. Helsinki: University of Helsinki.

Iso suomen kielioppi (ISK) [The big Finnish grammar]. 2004. Auli Hakulinen, Maria Vilkuna, Riitta Korhonen, Vesa Koivisto, Tarja Riitta Heinonen \& Irja Alho (eds). Helsinki: SKS.

Ji, Shaojun. 2008. What do paragraph divisions indicate in narrative texts? Journal of Pragmatics 40(10). 1719-1730.

Korpela, Jukka. 2004-2012. Nykyajan kielenopas [Language guide of today]. Tampere: Tampere University of Technology. http://www.cs.tut.fi/ jkorpela/kielenopas/index.html (accessed 18 January 2014).

Lehiste, Ilse. 1975. The phonetic structure of paragraphs. In Antonie Cohen \& Sibout G. Nooteboom (eds), Structure and process in speech perception, 195-206. New York: Springer.

Lehtinen, Mari. 2010. The recategorisation of the rheme and the structure of the oral paragraph in French and in Finnish. Discours 7. http://discours.revues.org/8007 (accessed 18 January 2014).

Lyytikäinen, Erkki. 1995. Naisten sävel [Women’s tone]. In Erkki Lyytikäinen (ed.), Bikinirajaus - näkökulmia kieleen [The bikini line - perspectives to language], 54-55. Helsinki: SKS.

Morel, Mary-Annick. 2010. Complexité des marqueurs de frontière dans le dialogue oral en français. In Nelly Andrieux-Reix (ed.), Frontières du linguistique au sémiotique, 17-37. Limoges: Lambert-Lucas.

Morel, Mary-Annick \& Laurent Danon-Boileau. 1998. Grammaire de l'intonation. L'exemple du français parlé. Paris \& Gap: Ophrys.

Nafá Waasaf, María Lourdes. 2007. Intonation and the structural organisation of texts in simultaneous interpreting. Interpreting 9(2). 177-198.

Nuolijärvi, Pirkko \& Liisa Tiittula. 2010. Irony in political television debates. Journal of Pragmatics 43(2). 572-587.

Ogden, Richard \& Sara Routarinne. 2005. The communicative functions of final rises in Finnish intonation. Phonetica 62. 160-175.

Pierrehumbert, Janet. 1980. The phonology and phonetics of English intonation. Cambridge, MA: Massachusetts Institute of Technology.

Routarinne, Sara. 2003. Tytöt äänessä. Parenteesit ja nouseva sävelkulku kertojan vuorovaikutuskeinoina [Girls talking. Parentheses and rising pitch as an interactional resource of the narrator]. Helsinki: SKS.

Sadeniemi, Matti. 1949. Metriikkamme perusteet [The basics of our metrics]. Helsinki: SKS.

Schegloff, Emanuel. 2002. Opening sequencing. In James E. Katz \& Mark Aakhus (eds), Perpetual contact: Mobile communication, private talk, public performance, 326-385. Cambridge: Cambridge University Press.

Sluijter, Agaath \& Jacques Terken. 1993. Beyond sentence prosody: Paragraph intonation in Dutch. Phonetica 50. 180-188.

Stark, Heather A. 1988. What do paragraph markings do? Discourse Processes 11(3). 275-303.

Tiittula, Liisa. 2009. SpeechText: Research on print interpreting. In Proceeding of 2nd International Seminar on Real-Time Intralingual Subtitling, Universitat Autònoma de Barcelona, 19 June. http://www.cs.uta.fi/speechtext/docs/Tiittula_ISRIS_2009.pdf (accessed 18 January 2014). 
Wichmann, Anne. 2000. Intonation in text and discourse. Beginnings, middles and ends. Harlow: Pearson Education.

Wiklund, Mari. 2013. Puheen prosodian ja kirjoitetun kohdetekstin suhde suomenkielisessä kirjoitustulkkausaineistossa [The relationship between the prosody of speech and the written target text in Finnish print interpreting data]. Puhe ja kieli [Speech and Language] 3. 107-130. http://ojs.tsv.fi/index.php/pk/article/view/9431/6722 (accessed 18 January 2014).

Yule, George. 1980. Speakers' topics and major paratones. Lingua 52. 33-47.

\section{Bionote}

Mari Wiklund (née Lehtinen) received her $\mathrm{PhD}$ in French philology at the University of Helsinki in 2009. Her dissertation concerned French prosody. In 2009-2010, she worked as a university lecturer. In 2011-2012 she worked as a post-doctoral researcher in a project called "Print interpreting: process, comprehensibility, and technology," funded by the Academy of Finland. Currently, her main research project concerns Asperger children's interaction (prosody, gaze behavior, and misunderstanding situations). Address for correspondence: Department of Modern Languages, PO Box 24, 00014 University of Helsinki, Finland <mari.wiklund@helsinki.fi>. 